UDC 378:622

N.A. Nestoruk ${ }^{1}$, Cand. Sc. (Ed.), orcid.org/0000-0001-9769-4552,

V.V. Melnik ${ }^{2}$, Dr. Sc. (Phil.), Assoc. Prof., orcid.org/0000-0001-6028-4066,

S. N.Zinoviev ${ }^{3}$, Cand. Sc. (Tech.), Assoc. Prof., orcid.org/0000-0002-0304-2332,

P. O. Chykunov ${ }^{4}$, Cand. Sc. (Tech.), orcid.org/0000-0003-4959-7744

\section{DOI: $10.29202 / \mathrm{nvngu} / 2018-5 / 18$}

1 - Horlivka Institute of Foreign Languages of the State Higher Educational Institution "Donbas State Pedagogical University”, Bakhmut, Ukraine, e-mail: natasha.nestoruk @yandex.ua 2 - Donbass State Pedagogical University, Slavyansk, Ukraine 3 - State Higher Educational Institution "Donetsk National Technical University", Pokrovsk, Ukraine

4 - State Higher Educational Institution "Educational-Scientific Professional-Pedagogical Institute of Ukrainian Engineering Pedagogics Academy”, Bakhmut, Ukraine

\title{
MODEL TOOLS FOR MASTERING ENGINEERING EXPERIMENTATION
}

Purpose. Creating a model that allows improving professional training of mining electrical engineers to capture engineering experimentation.

Methodology. An approach is proposed for creating a model that has the property of adapting to changes in the experimental environment, within the framework of which various properties of electromechanical systems are accessible for research. To achieve the goal, solve the problems and set out to test the effectiveness of the developed training technology, a set of complementary scientific methods is used, reflecting the dialectical unity of theoretical and empirical levels of knowledge: a specially designed set of tasks, a survey in the form of an individual questionnaire, observation and evaluation of training future engineers to perform electro-profile experimental research in the study of technical subjects. The approach is based on a complex of competences and must occur under certain conditions, among which the most important are its proper material and technical and methodological support; step-by-step planning; creation of a single educational and methodical environment; presence of a set of relevant academic disciplines; providing favorable motivational support. But the main pedagogical condition that ensures the implementation of a competently oriented teaching methodology is use of such didactic principles as determinism, systematicity, differentiation, variability, integrity and interactive learning.

Findings. The essence of experimental studies is clarified, notions of "experimental research" and "engineering experimentation" are identified, targets, content and technological components of the training of future mining engineers in the context of a tedious problem in accordance with the personality-oriented educational paradigm are specified. Based on the analysis of the future specialist's activities, in accordance with the competence complex, a structural model for training mining engineers-electromechanicians for conducting experimental studies has been developed, which makes it possible to improve the professional training of the future specialist.

Originality. A crucial task to create a model tool that facilitates adaptation to future professional activities is solved. A structural model of vocational training for mining engineers-electromechanicians has been developed, which is based on a set of factors. In the aggregate, they determine the model of training specialists that is aimed at mastering the competences of the conceptual, theoretical, systemic and technological levels, based on the content of technical disciplines, where engineering experimentation is its connecting core.

Practical value. Practical importance of the research is motivated by the fact that as a result of scientific search, based on the developed model presented, a training manual and other teaching materials have been developed and introduced into the vocational training of future engineers of the electromechanical profile, which have increased the level of students' preparation for engineering experimentation in future professional activities.

Keywords: experimental research, engineering experimentation, competent oriented basis, technical disciplines, structural model, training of mining engineers-electromechanicians

Introduction. Society and modern production make constantly growing demands on the training of engineering personnel for the provision of industrial enterprises. The main criterion in this case is the level of competence of a specialist and the quality of his/her preparation for professional activity, the leading role for which is played by engineering and technical literacy, professional culture, to which specialists specially pay attention. Study of the practice of future mining engineers-electromechanicians training for experimental research in the context of sociocultural conditions for the development of society, links between experimental activities in the competence development of specialists in the electromechanical profile made it possible to realize the importance of the

(C) Nestoruk N.A., Melnik V.V., Zinoviev S. N., Chykunov P. O., 2018 problem being studied for vocational training, which should provide not only an adequate level of theoretical knowledge, but also sufficient experience of experimental activity in the engineering sphere - that area in which a professional is going to work [1].

Experimental research is one of the production functions of an engineer, which is caused by the need to organize tests of prototypes or creating of original models, research on structural materials, and others. If we talk about engineering experimentation in electromechanicians' professional activity, we should first of all take into account the studies of meaningful interpretation of a theory of planning, organization and conducting of an experiment in electric drive, which were implemented, in particular, by B. Ivobotenko, M. Ilyinskyi, I. Kopylov, V. Kliuchev, B. Firago, L. Pavliachyk, as well as the work 
of A. Goldberg, which proposes a technique for electrical machines testing. Undoubted value of the last work involves the block diagrams developed by the author, on which algorithmization of industrial testing of machines can be carried out and which can serve as a basis for designing the experimental activity of students in the process of mastering the content of technical disciplines.

Adjustment of electric drive control systems, which can be a stage of engineering experiment, is developed and described only in the reference literature, despite the fact that the control system of electric drives is the subject of study in the training systems not only of electromechanicians, but also of other specialists.

Since the reference literature is a special edition, which, among other things, is characterized by a laconic and declarative statement of the setup stages, its application in the process of forming knowledge on tuning the electric drive at the algorithmic stage of preparing future specialists for an engineering experiment has certain features that require a methodical compilation. In particular, reference books do not contain a detailed exposition of the theoretical information, which is necessary to understand the semantic essence of the stages and individual actions. Also, they often lag behind the constructive and elemental base of practical control systems for electric machines.

From what has been said, it follows that it is necessary to master the technology of carrying out an engineering experiment, requires justification and definition of the relevant professional qualities, including professional skills. Thus, we have established that the specific weight and cognitive quality of experimental studies that can start in the study of technical disciplines, make it necessary to determine the proper organizational, managerial and methodical measures and means of influencing the course and results of training in order to master future mining electromechanical engineers' professional abilities that are necessary for experimental work, including in educational and pedagogical activities. This would make it possible to provide them with the ability to engineer experimentation and readiness to apply it in the further professional work in production.

Analysis of the recent research and publications. With the engineering experiment and experimental activities and the attendant questions of the engineering activity, methodological and methodological plan, a significant number of works of a different scientific direction and level are associated: from program articles to dissertation studies and teaching aids.

Various aspects of the preparation of students of technical universities for engineering experimental activities and the direct inclusion of engineering experimentation elements in the educational process of higher educational institutions were studied by S.Artiukh, A. Boiarshynova, R. Horbatiuk, V. Greene, S. Inozemtseva, A. Kaspersky, M. Spirin, N. Erganova, A. Fisher, V. Lavrov and other researchers.

Theoretical questions of engineering experimentation, on which the experimental activity of students is usually based while mastering the content of technical disciplines - are reflected at different times in the works of V. Gorskyi, Yu. Adler, A. Talalay, A. Yakovlev, A. Ego- rov, B. Ivobotenko, M.Ilinskyi, I. Kopylov, M. Spirin, L. Cherchik, H. Schenk, and others.

However, despite their different aspects and depth of study, the issues of training mining engineers-electromechanicians for conducting experimental research in the process of teaching technical disciplines remained without attention.

The purpose of the article is to present a structural model of vocational training for mining engineers-electromechanicians to master experimental research in the process of studying technical disciplines on a competently oriented basis.

Presentation of the main research. In engineering, as in many others activities, one of the methods of cognition is engineering experience. It is used in the design and development work, in the pilot and experimental stages of the development of a new technology and others. At the same time, engineering experience is applied limitedly in the process of technological or operational activities, and it is widely used in conducting experimental studies.

Limited application of the experiment in operational activities is due to the fact that the latter is oriented to servicing, industrial systems repair, as well as transporting, storing, preparing for the intended use (in particular installation, testing and commissioning) of production equipment. Operation involves monitoring the operation of equipment in order to ensure the optimal mode of its operation, control of its operation.

In the professional activity of specialists in the electromechanical profile, an important role is assigned to several areas that determine the subject-activity complex, which is formed by organizational and managerial and engineering-technical activities that cover the social and professional spheres of being a specialist [2].

Organizational and managerial activity of engineering employees provides systematic and purposeful leadership of the team in the production process.

Engineering and technical activity provides preparation of production, direct production, as well as maintenance of production facilities in the course of practical training. Engineering and technical activities have the following components: design, technology, research, and operational.

The design component of the electromechanical profile specialists' activity in practical terms is guided by the development of a new technology, refinement, modernization of the existing one. Results of the design activities are presented in the form of technical documentation designed to organize the production and operation of new equipment or the modernization of the existing one.

The technological component of the electromechanical profile specialist's activity ensures compliance with the design parameters of those production processes in which future specialists participate in the acquisition of practical experience and skills in performing technological operations, notes V. V. Borisov [3].

The research component of the electromechanical profile specialist's activity is directed to obtaining new scientific knowledge, clarifying and generalizing the 
available notions. In the process of such activities, scientific assumptions are confirmed or disproved, new ways of solving known problems are searched, and so forth, which, in our opinion, is an important element in the formation of the competence basis for the future specialist, his/her readiness for practical activities.

Depending on which methods (theoretical or empirical) prevail in the study, individual steps that are listed above can become irrelevant and not be included in the research plan. But practically in any research a special place is given to the experiment.

A culture of experimentation has arisen around the lesson study model [4].

Since the experiment is usually a stage in a study in which, using certain empirical methods, some results are obtained, that are included in the so-called empirical research cycle, then in the future we can call this stage in the projection for educational activity experimental research and think of it as a cyclic process in which several mental acts (steps) are used, successively replacing each other and interpolating the researcher closer to the informative result, on the basis of which it will be possible to formulate conclusions and propose recommendations on the possible introduction of the obtained results into production or intellectual activity.

Experimental studies are studies based on an experiment, which is based on scientific experience or observing a phenomenon under given conditions and allows you to monitor its progress, control it, obtain the necessary data and restore it when the initial conditions are repeated.

Since there is a significant list of technical disciplines in the system of training specialists in the electromechanical profile ("Theory of electric drive", "Electric machines", "Elements of automated electric drive", "Theory of automatic control", and others) and their training programs envisaged to apply not only theoretical but also empirical methods for acquiring knowledge, then experimental research in the study of these disciplines should be an integral part of learning.

"The subject of the technical disciplines study involves real objects of practice - mechanisms, devices, machines, means of their construction, the effectiveness of their functioning, and others. These disciplines examine large classes of homogeneous objects (technical devices and machines of a certain class) and look for a correlation and transformations that make it possible to reduce complex and cumbersome tasks and calculations to simple ones. At the same time, theoretical knowledge is not separated from practice (as in natural sciences), but is combined with it" [5].

Experimental research in the professional activity of electrical engineers begins to form the professional competencies (qualities) of the specialist, active management of the cognitive process associated with the analysis of the qualitative and quantitative characteristics of those objects, properties, qualities, characteristics, magnitudes, and so forth, are investigated in the experiment. Specificity of experimental studies in the activity of electromechanicians is the fact they are carried out for:
- theoretical obtaining of analytic dependence, which uniquely and exhaustively characterizes the investigation process;

- establishment of the dependence by theoretical means (which leads to an increase in the scope of the experiment);

- implementation of search activities to establish dependencies, which could not be obtained theoretically [5].

Based on the study of the practice of preparing students in the electromechanical profile, it was found out that professional competence in the projection on experimental research activities of mining electromechanical engineers should be based (except for social, personal, general scientific and instrumental competences) on general professional and specialized professional competencies.

Among the general professional competencies that play a significant role in experimental research are those that are directed to:

- formation of basic ideas about electromechanical devices (objects), their diversity, understanding of their purpose and principles of work;

- mastering the methods of observation, description, identification, finding the features of the electromechanical devices (objects) functioning;

- maintenance of actions and operating modes of electromechanical devices (objects).

Among the specialized professional competencies required for the experimental and research activity of mining engineers of the electromechanical profile are the following:

- to analyze, plan and organize experimental studies of electromechanical devices (objects);

- to apply general, technological, analytical and special methods of experimental research to determine statistical and dynamic characteristics, modes of operation of electromechanical devices (objects);

- to use professionally profiled knowledge in the field of electromechanics for statistical processing of experimental data and mathematical modeling of electromechanical phenomena and processes;

- to apply the mathematical apparatus in engineering experimentation.

It has been established that the training of mining electromechanical engineers for experimental research is based on interrelated and interdependent subject-activity, functional-content and organizational-activity components, which, in the aggregate of relationships, determine the structure of vocational training aimed at mastering the competences of the conceptual, theoretical, systemic and technological levels on the content of technical disciplines for which the core is engineering experimentation.

The subject-activity components of electrical engineers training for carrying out experimental studies include:

- regularities of the student's educational activity and methodical activity of the teacher;

- motivational factors for mastering the subject competencies (knowledge, skills, experience, worldview), which are formed on the content of technical disciplines; 
- cognitive activity of the subject of training;

- reflexive interaction with other subjects of the educational process;

- communication tools that provide an adequate understanding and broadcasting of information that is the subject of exchange, including its values.

The functional components in general reflect the conceptual framework, theoretical and methodological approaches, didactic instruments and technological constructivism, oriented to rational expediency and economy in teaching aids and techniques, which allow implementing the training objectives of electrical engineers of experimental research in the process of teaching technical disciplines. In particular, they characterize the gnostic, logical, design, integrative, constructive, organizational, regulatory orientation of the professional training of future electrical engineers for practical activities.

The methodological component serves the purpose of determining the methodological basis on which the training of electrical engineers will be based for carrying out experimental research in the process of technical disciplines teaching.

The structural and logical component is based on those conceptual foundations that position each technical discipline in the overall world outlook, intellectual and professional development of a specialist in the electromechanical profile, and provides such organization of the content of the academic discipline that allowed achieving the proper quality of practical training of graduates through the priority of engineering experimentation.

The instrumental-effective component characterizes a set of those didactic objects that provide methodological and instrumental support for educational activities aimed at assimilating the content of technical disciplines, provided that it reflects the tasks that require experimental research.

Instrumental support of educational activity presupposes the isolation from the whole variety of existing methods, means and methods of those which, by activity characteristics, can be considered expedient for application in carrying out experimental studies in the process of assimilating the content of technical disciplines.

Methodological support implies a choice among the known approaches to the organization of training (humanistic, axiological, personal, activity, resource, system, synergetic, competence, and others) that meets the normative requirements for specialists of the appropriate educational level, as well as the definition of priority styles for the presentation of the content of educational disciplines and the organization of educational activities aimed at its assimilation.

The organizational-technological component ensures organization and conducting of experimental research in the assimilation of the content of technical disciplines as an organic component of educational activity carried out by a specific technology, which is designed in accordance with the conceptual foundations and theoretical and methodological approaches to realizing the training goals of electrical engineers. This component is based on the methodological and techno- logical competence of the teacher, a specific manifestation of which is the subject-oriented integrative competence education as a professional quality of his/her personality.

The curative-effective component includes diagnostic and criterial-evaluative tools that allow carrying out current and final control over the progress of the future specialist's mastering knowledge and skills of conducting experimental studies in the process of assimilating the content of technical disciplines, and also through feedback to use corrective measures.

By objectifying and combining the components of the process of electromechanic engineers preparing for carrying out experimental research in the assimilation of the content of technical disciplines, we will reach the following structure of professional training (Figure), aimed at mastering the different level competencies characterizing the methodological preparedness of the future specialist.

Information development, achieved by society in the last decades, has caused the spread of computer tools and new information tools in all spheres of human activities, in particular, in engineering, engineering and technical, statistics and mathematics, and others. A certain part of such information tools is implemented in computer applications suitable for use in experimental studies in the process of assimilating the content of technical disciplines.

This does not exclude the possibility of not only direct application of these in the conduct of electromechanical experiments, but also the modeling with their help of an experimental medium within which various properties of electromechanical systems are accessible for research.

In the process of preparing specialists for conducting experimental research while mastering the content of technical disciplines, in addition to practical exercises, they take laboratory work, since it provides the opportunity to directly simulate situations in which the engineering experiment is the main means of obtaining information for decision-making, and also provide a source of practical experience for experimental activities. Learning objectives may include various ways of performing, depending on the available tools, data processing facilities, and others.

The articles [6, 7] contain a description of experiments and modeling in the ANSYS and SolidWorks Simulation application environments. Such works in the direction of specialists training is desirable to use as a basis for the development of teaching methods by means of the presented research.

Based on this, we can assume that the involvement of mining engineers of electromechanical specialties in experimental activities must occur under certain conditions, among which the most important are its proper material and technical and methodological support; step-by-step planning; creation of a single educational and methodical environment; presence of a set of relevant academic disciplines; providing favorable motivational support. But the main pedagogical condition that ensures the implementation of a competently oriented teaching technology is use of such didactic principles as: determinism, systematicity, differentiation, variability, integrity and interactive learning. 


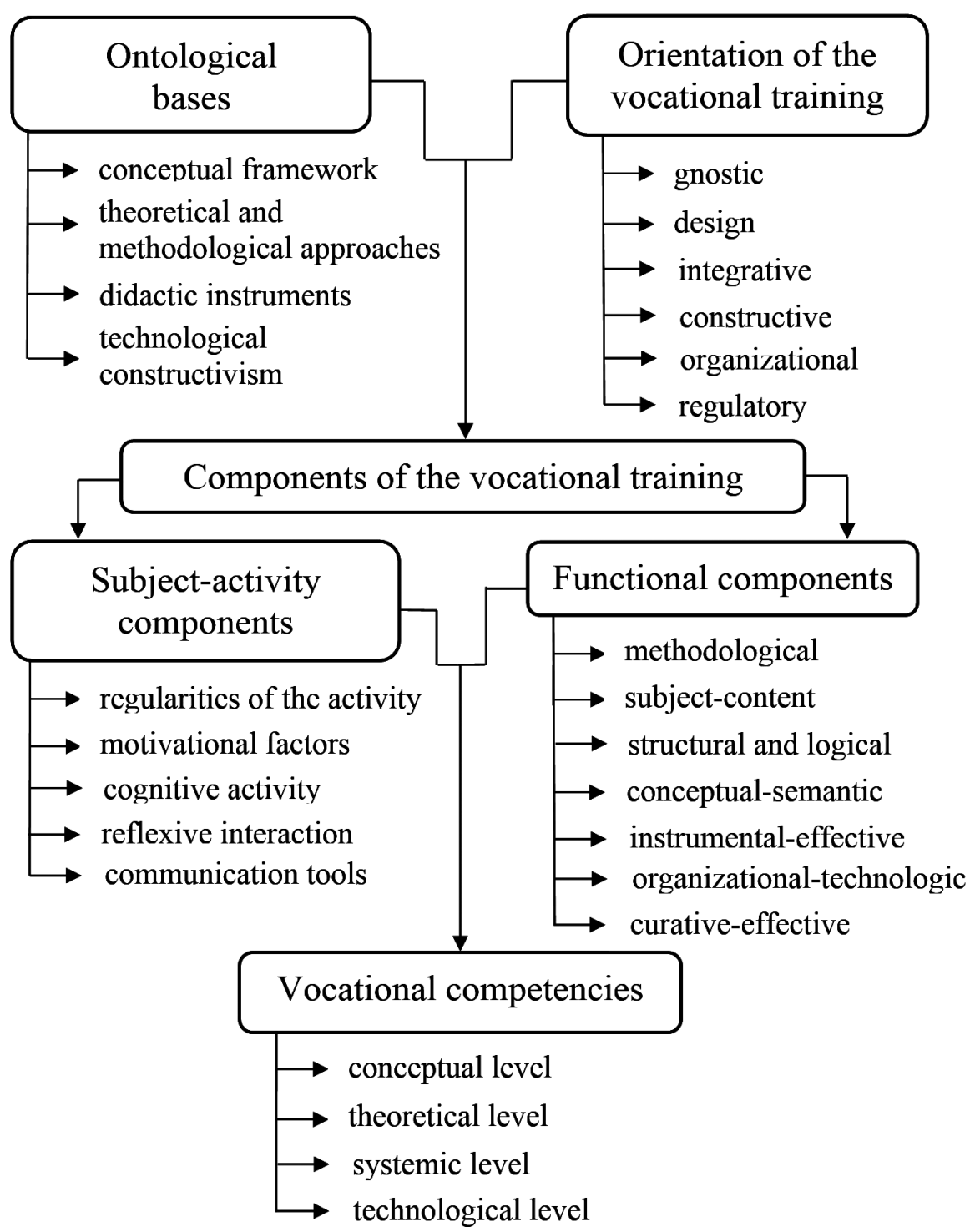

Fig. Structural model of vocational training for electrical engineers to master experimental research

Conclusions. Based on the practice study of mining engineers students of the electromechanical profile training, it has been established that experimental studies in the process of studying professionally oriented (technical) disciplines of electromechanical specialties have a leading role in forming a set of competencies in the future specialists sufficient for professional activity in conditions of a real production or training process and it is reasoned that the competence requirements for future engineers-electromechanicians in the formation of their capacity for professional activities that determine the content of student training, are directed to:

- formation of basic ideas about electromechanical devices (objects), their diversity, understanding of their purpose and principles of work;

- mastering the methods of observation, description, identification, finding the features of the electromechanical devices (objects) functioning;

- actions and operating modes of electromechanical devices (objects);

- acquisition of experience in analytical, planning and organizational activities in the process of experimental studies of electromechanical devices (objects);

- applying general, technological, analytical and special methods of experimental research to determine statistical and dynamic characteristics, modes of operation of electromechanical devices (objects);

- using professionally profiled knowledge in the field of electromechanics for statistical processing of experimental data and mathematical modeling of electromechanical phenomena and processes;

- applying the mathematical apparatus in engineering experimentation.

It was found out that the preparation of future mining engineers for experimental research activities must occur under certain conditions, among which the most important are its proper material and technical and methodological support; step-by-step planning; creation of a single educational and methodical environment; presence of a set of relevant academic disciplines; providing favorable motivational support. But the main pedagogical condition that ensures the implementation of a com- 
petently oriented teaching methodology is use of such didactic principles as: determinism, systematicity, differentiation, variability, integrity and interactive learning.

According to the complex of competences, a structural model was developed for training mining engineers-electromechanicians for carrying out experimental studies on the basis of analysis of the future specialist's activities, providing for design, research, technological and operational activities, as well as extensive application of the engineering experiment in the training of mining engineers, which allows adapting the future specialist to professional activities.

\section{References.}

1. Nestoruk, N.A., 2013. Experimental studies in the context of competence electromechanical teacher's engineers, Public education: Electronic scientific specialized edition [e-journal], 3(21). Available at: <http://www. narodnaosvita.kiev.ua/?page_id $=1451>$ [Accessed 25 September 2017].

2. Zarubinskaya, I. B., 2010. Formation of social competence of students of higher educational institutions (theoretical and methodological aspect). Kyiv: KNEU [online]. Available at: <http//www.zavantag.com/docs/ 531/index-29126.html $>$ [Accessed 2 October 2017].

3. Borisov, V. V., 2011. Use of design and engineering tasks in the lessons of labor training, Newsletter of the Chernigov State Pedagogical University named T. G. Shevchenko, 93. Series: Teaching Science [online]. Available at: <http:// enpuir.npu.edu.ua/handle/123456789/8304> [Accessed 22 September 2017].

4. National Academies of Sciences, Engineering, and Medicine, 2015. Science Teachers' Learning: Enhancing Opportunities, Creating Supportive Contexts. Washington, DC: The National Academies Press.

5. Gryzun, L. E., 2017. Didactic analysis of the educational subjects of different types in the process of forming the content of higher professional education, Public education. Electronic scientific specialized edition [online]. Available at: <https://www.narodnaosvita.kiev. ua/Narodna_osvita/vupysku/18/statti/grizun.htm > [Accessed 09 January 2018].

6. Zabolotny, K., Zinovyev, S., Zupiev, A. and Panchenko, E., 2015. Rationale for the parameters equipment for rope dehydration of mining hoisting installations. New Developments in Mining Engineering 2015. Theoretical and Practical Solutions of Mineral Resources Mining. CRC Press/Balkema, pp. 275-281.

7. Zabolotny, K., Zhupiev, O. and Molodchenko, A., 2015. Analysis of current trends in development of mine hoists design engineering. New Developments in Mining Engineering 2015. Theoretical and Practical Solutions of Mineral Resources Mining. CRC Press/Balkema, pp. $175-179$.

\section{Модельний інструментарій опанування інженерним експериментуванням}

\author{
Н. А. Несторук ${ }^{1}$, В. В. Мельник ${ }^{2}$, С. М. Зінов'єв ${ }^{3}$, \\ П. О. Чикунов ${ }^{4}$
}

1 - Горлівський інститут іноземних мов Державного вищого навчального закладу „Донбаський державний педагогічний університет“, м. Бахмут, Україна, e-mail: natasha.nestoruk@yandex.ua

2 - Донбаський державний педагогічний університет, м. Слов'янськ, Україна

3 - Індустріальний інститут Державного вищого навчального закладу „Донецький національний технічний університет“, м. Покровськ, Україна

4 - Навчально-науковий професійно-педагогічний інститут Української інженерно-педагогічної академії, м. Бахмут, Україна

Мета. Створення моделі, що дозволяє на компетентнісно-орієнтованій основі вдосконалити фахову підготовку гірничих інженерів-електромеханіків до опанування інженерним експериментуванням.

Методика. Запропоновано підхід для створення моделі, що має властивість адаптації до змін експериментального середовища, у межах якого виявляються доступними для дослідження різні властивості електромеханічних систем. Для досягнення мети, розв'язання сформульованих задач і перевірки ефективності розробленої технології навчання використана сукупність взаємодоповнюваних наукових методів, що відбивають діалектичну єдність теоретичного та емпіричного рівнів пізнання: спеціально розроблений комплект завдань, опитування у формі індивідуального анкетування, спостереження та оцінювання рівнів підготовки майбутніх інженерів електромеханічного профілю до виконання експериментальних досліджень при вивченні технічних дисциплін. Підхід базується на комплексі компетентностей і має відбуватися за певних умов, серед яких першочерговими є: належне матеріально-технічне й методичне забезпечення; поетапність у плануванні; створення єдиного навчально-методичного середовища; наявність комплексу відповідних навчальних дисциплін; забезпечення сприятливого мотиваційного супроводження. Основною педагогічною умовою, що забезпечує реалізацію компетентнісно-орієнтованої методики навчання, є застосування таких дидактичних принципів, як: детермінованість, систематичність, диференційованість, варіативність, інтегративність та інтерактивність навчання.

Результати. Уточнена сутність експериментальних досліджень, де поняття „експериментальні дослідження“ й „інженерне експериментування“ ототожнюються, цільові орієнтири, змістові й технологічні складники підготовки майбутніх гірничих інженерів у контексті студійованої проблеми відповідно до особистісно-орієнтованої парадигми освіти. На основі аналізу діяльності майбутнього фахівця, відповідно до комплексу компетентностей, була розроблена структурна модель підготовки гірничих інженерів-електромеханіків до проведення експериментальних досліджень, що дозволяє вдосконалити професійну підготовку майбутнього фахівця.

Наукова новизна. Вирішене актуальне завдання створення модельного інструментарію, що сприяє 
адаптації до майбутньої професійної діяльності. Розроблена структурна модель фахової підготовки гірничих інженерів-електромеханіків до опанування експериментальних досліджень, в основу якої покладено комплекс складників. У сукупності вони визначають модель підготовки фахівців, спрямовану на опанування компетентностями концептуального, теоретичного, системного, технологічного рівнів, що базуються на змісті технічних дисциплін, для яких наскрізним об'єднуючим стрижнем є інженерне експериментування.

Практична значимість. Унаслідок наукового пошуку на основі розробленої презентованої моделі створені та упроваджені в систему професійної підготовки майбутніх інженерів електромеханічного профілю навчальний посібник та інші навчальнометодичні матеріали, що підвищили рівень підготовки студентів до інженерного експериментування в майбутній професійній діяльності.

Ключові слова: експериментальні дослідження, інженерне експериментування, компетентнісно-орієнтована основа, технічні дисципліни, структурна модель, підготовка гірничих інженерів-електромеханіків

\section{Модельный инструментарий овладения инженерным экспериментированием}

\section{Н. А. Несторук ${ }^{1}$, В. В. Мельник ${ }^{2}$, С. Н. Зиновьев ${ }^{3}$, П. А. Чикунов ${ }^{4}$}

1 - Горловский институт иностранных языков Государственного высшего учебного заведения „Донбасский государственный педагогический университет“, г. Бахмут, Украина, e-mail: natasha.nestoruk@yandex.ua

2 - Донбасский государственный педагогический университет, г. Славянск, Украина

3 - Индустриальный институт Государственного высшего учебного заведения „Донецкий национальный технический университет“, г. Покровск, Украина

4 - Учебно-научный профессионально-педагогический институт Украинской инженерно-педагогической академии, г. Бахмут, Украина

Цель. Создание модели, позволяющей на компетентно-ориентированной основе усовершенствовать профессиональную подготовку горных инженеров-электромехаников к овладению инженерным экспериментированием.

Методика. Предложен подход для создания модели, имеющий способность адаптации к изменениям экспериментальной среды, в рамках которой оказываются доступными для исследования различные свойства электромеханических систем. Для достижения цели, решения сформулированных задач и проверки эффективности разработанной технологии обучения использована совокупность взаимодополняемых научных методов, отражающих диалектическое единство теоретического и эмпирического уровней познания: специально разработанный комплект заданий, опрос в форме индивидуального анкетирования, наблюдения и оценивания уровней подготовки будущих инженеров элек- тромеханического профиля к выполнению экспериментальных исследований при изучении технических дисциплин. Подход базируется на комплексе компетенций и должен выполняться при определенных условиях, среди которых первоочередными являются: материально-техническое и методическое обеспечение; поэтапность в планировании; создание единой учебно-методической среды; наличие комплекса соответствующих учебных дисциплин; обеспечение благоприятного мотивационного сопровождения. Основным педагогическим условием, обеспечивающим реализацию компетентно-ориентированной методики обучения, является применение таких дидактических принципов, как: детерминированность, систематизация, дифференцирование, вариативность, интегративность и интерактивность обучения.

Результаты. Уточнена сущность экспериментальных исследований, где понятия „экспериментальные исследования“ и „инженерное экспериментирование“ отождествляются, уточнены целевые ориентиры, содержание и технологические составляющие подготовки будущих горных инженеров в контексте личностно-ориентированной парадигмы образования. На основе анализа деятельности будущего специалиста, в соответствии с комплексом компетенций, разработана структурная модель подготовки горных инженеров-электромехаников к проведению экспериментальных исследований, которая позволяет усовершенствовать профессиональную подготовку будущего специалиста.

Научная новизна. Решена актуальная задача создания модельного инструментария, способствующего адаптации к будущей профессиональной деятельности. Разработана структурная модель профессиональной подготовки горных инженеров-электромехаников к овладению экспериментальными исследованиями, в основу которой положен комплекс факторов. В совокупности они определяют модель подготовки специалистов, направленную на овладение компетенциями концептуального, теоретического, системного, технологического уровней, основанными на содержании технических дисциплин, для которых сквозным объединяющим стержнем является инженерное экспериментирования.

Практическая значимость. Вследствие научного поиска на основе разработанной модели созданы и внедрены в систему профессиональной подготовки будущих инженеров электромеханического профиля учебное пособие и учебно-методические материалы, которые позволили повысить уровень подготовки студентов к инженерному экспериментированию в будущей профессиональной деятельности.

Ключевые слова: экспериментальные исследования, инженерное экспериментирование, компетентностно-ориентированный подход, технические дисииплины, структурная модель, подготовка горных инженеров-электромехаников

Рекомендовано до публікації докт. техн. наук К. Є. Даром. Дата надходження рукопису 05.09.17. 